Палій А. П., доктор сільськогосподарських наук,

Іщенко К. В., кандидат сільськогосподарських наук

Харківський національний технічний університет сільського господарства імені П. Василенка

\title{
ДОСЛІДЖЕННЯ ОСОБЛИВОСТЕЙ ЗАВЕРШЕННЯ МАШИННОГО ДОЇННЯ ВИСОКОПРОДУКТИВНИХ КОРІВ НА КОМПЛЕКСАХ ПРОМИСЛОВОГО ТИПУ
}

\author{
Рецензент - кандидат сільськогосподарських наук С. А. Нагорний
}

Мета статmі - дослідження технологічних особливостей завершення машинного дойння високопродуктивних корів на доїльних установках за різного часу затримки знімання дойльних апаратів.

Методика дослідження. Науково-господарські досліди проводили на сучасних дойльних установках «Паралель» фірми «Вои Матіс», у яких заключні операџії машинного додоювання та зняття доїльних стаканів відбувається за допомогою пневмоавтомата і маніпулятора.

Для встановлення ступеня впливу затримки знімання доїльного апарата з вимені високопродуктивних корів після закінчення машинного доӥння на показники молоковиведення та стан їхнього здоров'я провели науково-господарський дослід методом періодів на 3-х групах-аналогів украӥнської чорно-рябої молочної породи, по 15 голів у кожній.

Результати дослідження. За результатами аналізу показників молоковиведення високопродуктивних корів при затримиі знімання доӥльного апарата з вимені після припинення прочесу дойння, час якого становив 8, 12 та 15 с, встановлено, щуо всі вони не мали вірогідних відмінностей. При цьому спостерігали дещь більші витрати часу оператором на доӥння корів при затримщі 15 с, однак кількість видоєного молока за першу хвилину доӥння мала тенденцію до зменшення в корів при затримщі на 8 с за величини ручного додоювання 0,10 кг проти 0,07-0,09 к2, при затримиі знімання апарата відповідно на 12 ma $15 \mathrm{c}$.

Елементи наукової новизни. Одержано нові дані щодо впливу технологічних прийомів завершення машинного доӥння високопродуктивних корів на доӥльних установках в умовах комплексів промислового типу на зниження травмування вимені корів, збільшення інтенсивності й повноти видоювання та підвищення продуктивності праці оператора машинного доӥння.

Практична значущість. На підставі досліджень експериментально обтрунтовано доцільність використання техніко-технологічних рішень доїння високопродуктивних корів, які не чинять негативного впливу на тварин, забезпечують високі показники молоковиведення та отримання продукції вищого татунку.

Ключові слова: доӥння, високопродуктивні корови, вим'я, заключні операчії, показники молоковиведення.

Палій Андрій Павлович - доктор сільськогосподарських наук, доцент кафедри технічних систем та технологій тваринництва, Харківський національний технічний університет сільського господарства ім. П. Василенка, Московський пр., 45, м. Харків, 61050, Україна, e-mail: paliy.andriy@ukr.net, ORCID ID: 0000-0001-9525-3462.

Іщенко Катерина Вікторівна - кандидат сільськогосподарських наук, кафедра технічних систем та технологій тваринництва, Харківський національний технічний університет сільського господарства ім. П. Василенка, Московський пр., 45, м. Харків, 61050, Україна, e-mail: kaktjav@gmail.com, ORCID ID: 0000-0003-4542-0669.

Постановка проблеми. Організація доїння корів є одним із найважливіших процесів у виробництві молока. Машинне доїння корів дозволяє поліпшити трудові умови операторів і підвищити продуктивність праці, знизити собівартість виробництва молока і підвищити його якість. Для механізації процесу доїння застосовують різні доїльні установки. Машинне доїння дозволяє об’єднати в собі відразу декілька трудомістких процесів: отримання і збір молока від корів, його транспортування в молочну, охолодження і короткострокове зберігання. У результаті знижується рівень трудових витрат на фермі, поліпшуються санітарно-гігієнічні умови.

Поряд 3 цим залишається не вивченим питання впливу доїльних систем на високопродуктив- 


\section{TEХНIЧНI НАУКИ}

них корів під час проходження процесу видоювання.

Аналіз останніх досліджень і публікацій, у яких започатковано розв'язання проблеми. До заключних операцій доїння високопродуктивних корів можна віднести процеси додоювання та зняття доїльного апарата з вимені корови, оброблення вимені дезінфікуючими розчинами.

Рефлекс молоковіддачі триває недовго і припиняється незалежно від того, видоєна корова чи ні. Цю особливість необхідно враховувати при машинному доїнні, закінчуючи видоювання корови під час дії рефлексу молоковіддачі, тобто коли молоко найбільш інтенсивно надходить у молочні цистерни. Чим швидше доять корову, тим краще і повніше спорожняється їі вим'я. У процесі доїння спочатку звільняється цистерна, потім протоки і в останню чергу - альвеоли, а альвеолярне молоко найжирніше. Тому доїння понад 6-7 хв. негативно позначається на продуктивності загалом і на жирності молока [2].

Одночасно пропонуються різні технологічні прийоми та засоби підготовки високопродуктивних корів до машинного доїння [9]. Ефективність цих технологій на сучасних вітчизняних молочних комплексах залишається маловивченим питанням.

Поряд із цим залишається невирішеним питання необхідності обгрунтування прийому додоювання високопродуктивних корів із річним надоєм 6000-8000 кг молока й встановлення впливу затримки знімання доїльного апарата 3 вимені після закінчення процесу молоковиведення [4].

Повне видоювання корів є важливим чинником для досягнення успіху в молочному скотарстві. Оскільки продукт додоювання має найвищий відсоток жиру, він є вирішальною ознакою для загальної якості молока та отримання високого прибутку [5].

Вчені $[3,6]$ вважають, що на кожному сучасному молочному комплексі необхідно використовувати технічні засоби для додоювання, тому що дослідження 3 використанням вимірювача молочного потоку свідчать, що навіть за наявності найудосконаленіших доїльних апаратів без додоювання у значної кількості корів залишається у вимені більше 200 грамів молока. Такої ж думки дотримуються й інші дослідники [8].

Отже, при режимі механічного додоювання можливо отримати деяке збільшення надоїв молока. Але, водночас, чимало вчених і практиків висловлюють думку про те, що від процесу до- доювання можна відмовитися, не втрачаючи при цьому значної кількості молока і не піддаючи небезпеці стан здоров'я тварини, якщо всі попередні операції були проведені якісно. Ці науковці вважають, що загальні витрати праці на додоювання та одержання залишку молока $є$ економічно не вигідними і дотримуючись певних вимог, таких як стимуляція, бездоганне функціонування доїльного апарата, добра та якісна дійкова гума, привчені корови і кваліфіковані оператори машинного доїння, можна відмовитися від додоювання [1, 4]. Водночас, на світовому ринку доїльномолочного обладнання пропонують i знаходять застосування на практиці доїльні установки, у яких після досягнення певної найменшої кількості потоку молока доїльні апарати автоматично знімаються 3 вимені корови без будь-якого додоювання.

Досвід багатьох зарубіжних молочно-товарних господарств свідчить про можливість виключення операції машинного додоювання 3 переліку обов' язкових заключних операцій [10].

Разом із цим [7] вважають, що машинне додоювання може викликати більше проблем відносно стану здоров' я тварин, ніж відмова від нього.

Дослідження та вирішення зазначених питань представляють як практичний, так i науковий інтерес.

Мета даної роботи полягала у дослідженні технологічних особливостей завершення машинного доїння високопродуктивних корів на доїльних установках за різного часу затримки знімання доїльних апаратів.

Завдання досліджень полягало у визначенні впливу часу затримки знімання доїльного апарата з вимені корів після закінчення процесу доїння на показники молоковиведення та стан здоров'я тварин.

Матеріали та методи досліджень. Науковогосподарські досліди проводили на сучасних доїльних установках «Паралель» фірми «Bou Matic», у яких заключні операції машинного додоювання та зняття доїльних стаканів відбувається за допомогою пневмоавтомата і маніпулятора.

Для встановлення ступеня впливу затримки знімання доїльного апарата 3 вимені високопродуктивних корів після закінчення машинного доїння на показники молоковиведення та стан їхнього здоров'я провели науково-господарський дослід методом періодів на 3-х групах-аналогів української чорно-рябої молочної породи, по 15 гол. у кожній. Схему науково-господарського досліду представлено в табл. 1. 


\section{ТЕХНІЧНІ НАУКИ}

\section{1. Схема науково-господарського досліду}

\begin{tabular}{|c|c|}
\hline Група & Режими знімання доїльного апарата з вимені корів \\
\hline I (дослідна) & Затримка після закінчення потоку молока 200 мл $/$ хв + 8 с \\
\hline II (дослідна) & Затримка після закінчення потоку молока 200 мл/хв + 12 с \\
\hline III (дослідна) & Затримка після закінчення потоку молока $200 \mathrm{mл/хв} \mathrm{+} 15$ с \\
\hline
\end{tabular}

Джерело: власні дослідження.

2. Показники молоковиведення у корів при різній тривалості затримки знімання доїльних апаратів із вимені, $\left(X \pm S_{\vec{X}}\right)$

\begin{tabular}{|c|c|c|c|}
\hline \multirow{3}{*}{ Показник } & \multicolumn{3}{|c|}{ Тривалість затримки, с } \\
\hline & 8 & 12 & 15 \\
\hline & I група & II група & III група \\
\hline Кількість корів, голів & 15 & 15 & 15 \\
\hline Тривалість досліду, діб & 65 & 65 & 65 \\
\hline Кількість визначень, n & 45 & 45 & 45 \\
\hline 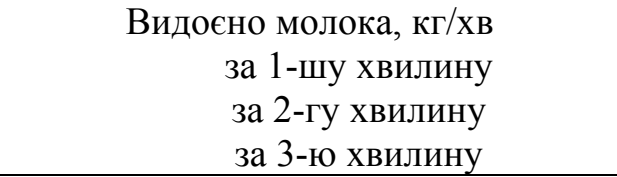 & $\begin{array}{l}2,57 \pm 0,45 \\
2,82 \pm 0,45 \\
2,65 \pm 0,31\end{array}$ & $\begin{array}{l}2,68 \pm 0,28 \\
2,77 \pm 0,43 \\
2,70 \pm 0,26\end{array}$ & $\begin{array}{l}2,65 \pm 0,36 \\
2,85 \pm 0,37 \\
2,78 \pm 0,38\end{array}$ \\
\hline Вилосно мопока апапатом кго\% & $13,95 \pm 1,22$ & $14,26 \pm 1,35$ & $14,35 \pm 1,26$ \\
\hline ВИдОенО молока аІІаратом, кГт\%о & 98,9 & 99,2 & 99,2 \\
\hline Тривалість видоювання апаратом, хв & $5,9 \pm 0,32$ & $6,2 \pm 0,42$ & $6,3 \pm 0,28$ \\
\hline Величина ручного додоювання, кг & $0,10 \pm 0,01$ & $0,07 \pm 0,02$ & $0,09 \pm 0,03$ \\
\hline $\begin{array}{c}\text { Середня інтенсивність молоковиве- } \\
\text { дення, кг/хв }\end{array}$ & $1,93 \pm 0,37$ & $1,92 \pm 0,43$ & $1,92 \pm 0,24$ \\
\hline $\begin{array}{l}\text { Позитивна реакція на приховану фо- } \\
\text { рму маститу }\end{array}$ & не виявлено & не виявлено & не виявлено \\
\hline
\end{tabular}

Джерело: власні дослідження.

Усіх корів у дослідний період видоювали однотипним апаратом із режимом автоматичного його знімання 3 вимені після закінчення потоку молока 200 мл/хв, але за різного часу затримки: корів I-ї групи - на 8 с, корів II-ї групи - на 12 c, корів III-ї групи - на 15 c.

Результати досліджень. Сучасні доїльні установки різняться за рівнем оснащення засобами автоматизації технологічних операцій машинного додоювання, тому що кількість молока, що одержують завдяки цій операції, становить у середньому від 300 до 500 г, а відсутність автоматизованої системи додоювання передбачає значні витрати ручної праці. Особливу увагу при цьому приділяють виконанню саме заключних операцій - машинному додоюванню і зніманню доїльних апаратів із вимені корів у кінці доїння при зниженні потоку молока (до 200-800 г/хв).

Показники молоковиведення та стан вимені корів при різній тривалості затримки знімання доїльних апаратів із вимені представлено в табл. 2.

За результатами аналізу показників моло- ковиведення високопродуктивних корів при затримці знімання доїльного апарата з вимені після припинення процесу доїння, час якої становив 8, 12 та 15 с, встановлено, що всі вони не мали вірогідних відмінностей. При цьому спостерігали дещо більші витрати часу оператором на доїння корів при затримці 15 с, однак кількість видоєного молока за першу хвилину доїння мала тенденцію до зменшення в корів при затримці на 8 с за величини ручного додоювання 0,10 кг проти 0,07-0,09 кг, при затримці знімання апарата відповідно на 12 та 15 с.

Слід зазначити, що протягом дослідного періоду позитивної реакції на приховану форму маститу не виявлено.

Використання різного часу затримки знімання доїльного апарата з вимені корів після процесу молоковиведення не мало негативного впливу на стан здоров'я тварин.

Отже, у процесі досліджень не встановлено переваги щодо застосування будь-якого часу затримки знімання доїльного апарата 3 вимені високопродуктивних корів після припинення про- 


\section{ТЕХНІЧНІ НАУКИ}

цесу молоковиведення, оскільки всі досліджені показники були майже на однаковому рівні і не мали вірогідних відмінностей.

Як шлях вирішення питання, пов'язаного 3 виконанням заключних операцій, автоматизація (роботизація) є альтернативою як 3 точки зору затрат праці, так і контролю за станом дійних корів.

Поряд 3 цим, враховуючи тенденції розвитку молочного скотарства у світі, автоматизація молочного підприємства $€$ найважливішим показником рівня його технічного розвитку. Забезпечуючи технологічні та економічні переваги, яких неможливо досягти під час традиційної організації виробництва, вона $\epsilon$ основою перспективного розвитку сучасної

\section{БІБЛІОГРАФІЯ}

1. Носевич Д. К., Роговик В. В. Інтенсивність доїння корів на доїльному майданчику. Науковий вісник Національного університету біоресурсів і природокористування Украӥни. 2016. Вип. 250: Серія «Технологія виробництва і переробки продукції тваринництва». С. 165-170.

2. Палій $A$. П. Інноваційні основи одержання високоякісного молока: монографія. Харків : Міськдрук, 2016. 270 с.

3. Палій А. П., Палій А. П. Технікотехнологічні інновації у молочному скотарстві: монографія. Харків : Міськдрук, 2019. 324 с.

4. Савиных П. А., Шулятьев В. Н., Рылов А. А. $\mathrm{K}$ вопросу холостого доения коров. Молочнохозяйственный вестник. 2018. № 1 (29). C. 134-143.

5. Сычева О. В. Молоко. Качество, состав, свойства: проблемы и решения. Москва-Берлин : Директ-Медиа. 2014. 145 с. DOI: 10.23681/ 273470.

6. Чеченихина О. С., Лиходеевская О. Е. Факторы, влияющие на уровень молочной продуктивности коров при доении в доильных залах. Вестник Новосибирского государственного аг-

\section{REFERENCES}

1. Nosevych, D. K., \& Rohovyk, V. V. (2016). Intensyvnist doinnia koriv na doilnomu maidanchyku [Intensity of milking cows on the milking site]. Naukovyi visnyk Natsionalnoho universytetu bioresursiv $i$ pryrodokorystuvannia Ukrainy, 250, Seriia «Tekhnolohiia vyrobnytstva $i$ pererobky produktsii tvarynnytstva», pp. 165-170 [In Ukrainian].

2. Palii, A. P. (2016). Innovatsiini osnovy oderzhannia vysokoiakisnoho moloka: monohrafiia. [In- молочної індустрії країни. Поглиблення рівня автоматизації в молочній промисловості має величезне значення, що проявляється через підвищення ефективності праці, поліпшення якості молочних продуктів, оптимальне використання виробничих ресурсів тощо, а подальший шлях прогресу в цьому напрямі створення «інтелектуальної ферми», у якій крім доїння, буде автоматизовано низку інших, найбільш важких робіт.

Висновок. Доведено, що затримка знімання доїльного апарата 3 вимені високопродуктивних корів після припинення процесу доїння, час якої становив 8, 12 та 15 с, суттєво не впливає на показники молоковиведення, стан здоров'я тварин та рівень захворювання на мастит.

рарного университета. 2018. № 48 (3). С. 108116. https://doi.org/10.31677/2072-6724-2018-48-3108-116.

7. Milking parlour size, pre-milking routine and stage of lactation affect efficiency of milking in single-operator herringbone parlours / B. O'Brien, J. Jago, J. P. Edwards et al. Journal of Dairy Research. 2012. Vol. 79 (2). P. 216-223. DOI: 10.1017/S0022029912000088.

8. Ming-Chih Chen, Chien-Hsing Chen, Chong$Y u$ Siang. Design of Information System for Milking Dairy Cattle and Detection of Mastitis. Mathematical Problems in Engineering. 2014. http://dx.doi.org/10.1155/2014/759019.

9. Research on high-yielding dairy cow treatment techniques during milking / A. Paliy, O. Nanka, K. Ishchenko, A. Paliy. ABAH Bioflux. 2019. Vol. 11 (1). P. 1-11. URL : http://www.abah.bioflux.com.ro/.

10. Stelwagen $K$. Effect of milking frequency on mammary functioning and shape of the lactation curve. Journal Dairy Science. 2001. Vol. 84 (supple). P. 204-211. DOI: 10.3168/jds.S00220302(01)70219-6.

novative foundations for the production of highquality milk: monograph]. Kharkiv: Miskdruk [In Ukrainian].

3. Palii, A. P., \& Palii, A. P. (2019). Tekhnikotekhnolohichni innovatsii u molochnomu skotarstvi: monohrafiia. [Technological and technological innovations in dairy cattle breeding: monograph]. Kharkiv: Miskdruk [In Ukrainian].

4. Savinyh, P. A., Shuljat'ev, V. N., \& Rylov, A. A. (2018). K voprosu holostogo doenija 


\section{ТЕХНІЧНІ НАУКИ}

korov [On the issue of idle milking of cows]. Molochnohozjajstvennyj vestnik, 1 (29), pp. 134-143 [In Russian].

5. Sycheva, O. V. (2014). Moloko. Kachestvo, sostav, svojstva: problemy i reshenija [Quality, composition, properties: problems and solutions]. Moskva-Berlin: Direkt-Media [In Russian].

6. Chechenihina, O. S., \& Lihodeevskaja, O. E. (2018). Faktory, vlijajushhie na uroven' molochnoj produktivnosti korov pri doenii $\mathrm{v}$ doil'nyh zalah [Factors affecting the level of milk production of cows during milking in the milking rooms]. Vestnik Novosibirskogo gosudarstvennogo agrarnogo universiteta, 48 (3), pp. 108-116 [In Russian].

7. O'Brien, B., Jago, J., Edwards, J. P., LopezVillalobos, N., \& McCoy, F. (2012). Milking parlour size, pre-milking routine and stage of lactation affect efficiency of milking in single-operator herringbone parlours. Journal of Dairy Research, 79 (2), pp. 216-223 [In English].

8. Ming-Chih, Chen, Chien-Hsing, Chen, \& Chong-Yu, Siang (2014). Design of Information System for Milking Dairy Cattle and Detection of Mastitis. Mathematical Problems in Engineering [In English].

9. Paliy, A., Nanka, O., Ishchenko, K., Paliy, A. (2019). Research on high-yielding dairy cow treatment techniques during milking. ABAH Bioflux, 11 (1), pp. 1-11 [In English].

10. Stelwagen, K. (2001). Effect of milking frequency on mammary functioning and shape of the lactation curve. Journal Dairy Science, 84(supple), pp. 204-211 [In English].

\section{Палий А. П., Ищенко К. В. Исследование особенностей завершения машинного доения высо- копродуктивных коров на комплексах промышленного типа}

Цель статьи - исследование технологических особенностей завершения машинного доения высокопродуктивных коров на доильных установках при разном времени задержки снятия доильных апnаратов.

Методика исследования. Научно-хозяйственные опыты проводили на современных доильных установках типа «Параллель» фирмы «Вои Матіс», в которых заключительные операции машинного додаивания и снятие доильных стаканов происходит с помощью пневмоавтомата и манипулятора.

Для установления степени влияния задержки снятия доильного аппарата с вымени высокопродуктивных коров после окончания машинного доения на показатели молоковыведения и состояние их здоровья провели научно-хозяйственный опыт методом периодов на 3-х группах-аналогов украинской черно-рябой молочной породы, по 15 голов в каждой.

Результаты исследования. По результатам анализа показателей молоковыведения высокопродуктивных коров при задержании снятия доильного аппарата с вымени после прекращения процесса доения, время которого составило 8, 12 и 15 с, установлено, что все они не имели достоверных различий. При этом наблюдали несколько большие затраты времени оператором на доения коров при задержании 15 с, однако количество выдоенного молока за первую минуту доения имело тенденцию к уменьшению у коров при задержании на 8 с при величине ручного додаивания 0,10 кг против 0,070,09 к2, при задержке съема аппарата соответственно на 12 и 15 с.

Элементы научной новизны. Получены новые данные о влиянии технологических приемов завершения машинного доения высокопродуктивных коров на доильных установках в условиях комплексов промышленного типа на снижение травмирования вымени коров, увеличение интенсивности и полноты выдаивания и повышения производительности труда оператора машинного доения.

Практическая значимость. На основании исследований экспериментально обоснована целесообразность использования технико-технологических решений доения высокопродуктивных коров, которые не оказывают негативного влияния на животных, обеспечивают высокие показатели молоковыведения и получение продукции высшего сорта.

Ключевые слова: доения, высокопродуктивные коровы, вымя, заключительные операции, показатели молоковыведения.

Палий Андрей Павлович - доктор сельскохозяйственных наук, доцент кафедры технических систем и технологий животноводства, Харьковский национальный технический университет сельского хозяйства им. П. Василенко, пр. Московский, 45, г. Харьков, 61050, Украина, е-таil: paliy.andriy@ukr.net, ORCID ID: 0000-0001-9525-3462.

Ищенко Екатерина Викторовна - кандидат сельскохозяйственных наук, кафедра технических систем и технологий животноводства, Харьковский национальный технический университет сельско- 
го хозяйства им. П. Василенко, пр. Московский, 45, г. Харьков, 61050, Украина, e-mail: kaktjav@gmail.com, ORCID ID: 0000-0003-4542-0669.

Paliy A. P., Ishchenko K. V. The investigation of the peculiarities of completing the machine milking of high-yielding cows on industrial type complexes

The purpose of the article is studying the technological peculiarities of completing the machine milking of high-yielding cows on milking installations at different time of delaying milking machines removal.

Methods of the research. Scientific experiments were conducted on modern milking machines of the "Parallel" type of "Bou Matic" firm, in which the final operations of machine after-milking and removing teat cups are carried out by using a pneumatic machine and a manipulator.

The scientific-economic experiment was conducted by the method of periods on 3 groups of Ukrainian black-and-white milk breed analogues, 15 heads in each to determine the degree of the delay influence in removing the milking machine from the udder of high-yielding cows after the finishing machine milking on the milk ejection indices and the cows' health condition.

The research results. According to the results of analyzing milk ejection indices of high-yielding cows with the delay of removing the milking machine from the udder after finishing the milking process (the delay time was 8, 12 and 15 seconds) it was established that they did not have any sufficient differences. At the same time, the operator spent more time on milking cows with the delay of 15 seconds, but the amount of the obtained milk in the first minute of milking tended to decrease in the cows with the delay of 8 seconds, and the amount of milk during hand after-milking was $0.10 \mathrm{~kg}$ in comparison with $0.07-0.09 \mathrm{~kg}$, with the delay of removing the machine, correspondingly, by 12 and 15 seconds.

The elements of scientific novelty. New data on influencing the technological methods of completing the machine milking of high-yielding cows on milking installations in the conditions of industrial complexes on reducing cow's udder injuries, increasing the intensity and completeness of milking, and raising the labor productivity of the machine milking operator have been received.

Practical significance. Based on the research, the feasibility of using technical-technological solutions for milking of high-yielding cows, which have no negative impact on animals, has been experimentally substantiated. Such solutions ensure high rates of milk ejection and obtaining higher-quality products.

Key words: milking, high-yielding cows, udder, final operations, milk ejection indices.

Paliy Andriy Pavlovych - Doctor of Agricultural Sciences, Associate Professor, Department of Technical Systems and Animal Husbandry Technologies, Kharkiv National Technical University of Agriculture named after P. Vasylenko, 45, Moskovskyi av., Kharkiv, 61050, Ukraine, e-mail: paliy.andriy@ukr.net, ORCID ID: 0000-0001-9525-3462.

Ishchenko Kateryna Viktorivna - Candidate $(\mathrm{PhD})$ of Agricultural Sciences, Department of Technical Systems and Animal Husbandry Technologies, Kharkiv National Technical University of Agriculture named after Petro Vasylenko, 45, Moskovskyi av., Kharkiv, 61050, Ukraine, e-mail: kaktjav@gmail.com, ORCID ID: 0000-0003-4542-0669.

Стаття надійшла до редакції 21.02.2019 р.

Бібліографічний опис для цитування :

Палій А. П., Іщенко К. В. Дослідження особливостей завершення машинного доїння високопродуктивних корів на комплексах промислового типу. Вісник ПДАА. 2019. № 1. С. 250-255.

DOI 10.31210/visnyk2019.01.30

(C) Палій Андрій Павлович, Іщенко Катерина Вікторівна, 2019 
Відповідальний редактор: Мельничук $B . B$.

Літературні редактори: Дедухно А. В., Жукова В. K.

Переклад англійською мовою: Панкова Т. О., Жукова В. К. Куратор з індексів DOI: Жукова $B . K$.

Комп'ютерна верстка та дизайн: Свєшнікова А. O.

Формат 60х90/8.Ум. друк. арк. 16,1. Тираж 300 пр. Зам. № 24.

Видавець і виготовлювач: Полтавська державна аграрна академія.

Адреса: 36003, м. Полтава, вул. Г. Сковороди, 1/3.

Свідоцтво суб’єкта видавничої справи ДК №2174 від 26.04.2005 